\title{
MICROCEPHALY-CAPILLARY MALFORMATION SYNDROME
}

Shchagina OA $\bowtie$, Semenova NA, Bessonova LA, Larshina EA, Beskorovainiy NS, Zakharova EYu, Ryzhkova OP, Poliakov AV

Research Centre for Medical Genetics, Moscow, Russia

Microcephaly-capillary malformation syndrome (MICCAP: OMIM 614261) is a severe monogenic disorder inherited in an autosomal recessive manner caused by mutations in the STAMBP gene. There are less than 20 published cases of the syndrome to date. The paper reports three new cases of rare MICCAP syndrome. The cause of the disorder was confirmed in three affected individuals from two unrelated families by pedigree analysis, biochemical analysis, RFLP analysis and automated Sanger sequencing. The two brothers were homozygous for the potentially pathogenic STAMBP gene variant c.188A>G (p. Tyr63Cys). Clinical phenotype of the girl from the second family resulted from the combination of two genetic disorders: galactosemia caused by the compound heterozygosity for the pathogenic GALT gene variants (c.563A>G and c.855G>T), and MICCAP caused by the STAMBP gene variants (c.204-5C>G and c.668_669delCA), one of which originated de novo. The prevalence of microcephaly-capillary malformation syndrome in Russia is evaluated, it is one per 120,000 people (Cl: 1/356 724-1/62 691). The carrier frequency is one per 173 people. The target STAMBP gene analysis makes the genetic confirmation of the MICCAP syndrome quicklier. When determining the tactics of diagnosis and therapy in each particular case, the possibility of combination of two rare genetic disorders in one patient should be considered.

Keywords: microcephaly, hemangioma, capillary malformation, STAMBP, galactosemia, GALT

Author contribution: Shchagina OA — study design, molecular genetic analysis, frequency estimation, statistical analysis; Semenova NA, Bessonova LA — clinical examination and genetic counseling of the patients' families; Larshina EA — biochemical assays, GALT gene analysis; Beskorovainiy NS — exome sequencing data processing; Zakharova EYu — biochemical analysis, prevalence calculation; Ryzhkova OP — pathogenicity analysis of genetic variants, exome sequencing; Poliakov AV — selection of primers for molecular genetic analysis.

Compliance with ethical standards: the study was approved by the Ethics Committee of the Research Centre for Medical Genetics (protocol № 5/8 dated November 12, 2018). The informed consent to molecular genetic testing, and anonymity-preserving clinical and molecular genetics data publishing (including photos and videos) was submitted by all participants or their legal representatives.

$\triangle$ Correspondence should be addressed: Olga A. Shchagina

Moskvorechye, 1, Moscow, 115522; schagina@dnalab.ru, schagina_o@mail.ru

Received: 18.05.2020 Accepted: 03.06.2020 Published online: 18.06.2020

DOI: $10.24075 /$ brsmu.2020.033

\section{СИНДРОМ МИКРОЦЕФАЛИИ В СОЧЕТАНИИ С КАПИЛЛЯРНЫМИ МАЛЬФОРМАЦИЯМИ}

\author{
О. А. Щагина 凶, Н. А. Семенова, Л. А. Бессонова, Е. А. Ларшина, Н. С. Бескоровайный, Е. Ю. Захарова, О. П. Рыжкова, А. В. Поляков
}

Медико-генетический научный центр имени Н. П. Бочкова, Москва, Россия

\begin{abstract}
Синдром микроцефалии в сочетании с капиллярными мальформациями (МICCAP) (ОМІМ \#614261) — тяжелое моногенное заболевание с аутосомнорецессивным типом наследования, причиной которого являются мутации гена STAMBP. На сегодняшний день в мировой литературе описано менее 20 случаев данного синдрома. В работе представлены три новых случая редкого синдрома МІССАР: на основании клинико-генеалогического анализа, методов биохимического исследования, анализа полиморфиима длин рестрикционных фрагментов, прямого автоматического секвенирования по Сенгеру установлена причина болезни у трех больных из двух неродственных семей. У двух братьев выявлен вероятно-патогенный вариант гена STAMBP c.188A>G (p. Tyr63Суs) в гомозиготном состоянии. У девочки из второй семьи причиной клинического фенотипа явилось сочетание двух наследственных заболеваний: галактоземии, обусловленной патогенными вариантами с.563A>G и с.855G>T гена GALT в компаунд-гетерозиготном состоянии и MICCAP, обусловленного вариантами с.204-5C>G и c.668_669delCA гена STAMBP, один из которых возник de novo. Оценены частота синдрома микроцефалии в сочетании с капиллярными мальформациями в России - один случай на 120000 человек (ДИ: 1/356 724-1/62 691) и частота носительства данного синдрома - один случай на 173 человека. Исследование гена STAMBP позволяет быстро найти молекулярно-генетическую причину синдрома MICCAP. При выборе тактики диагностики и терапии в каждом конкретном случае необходимо учитывать возможность сочетания у одного больного двух редких наследственных патологий.
\end{abstract}

Ключевые слова: микроцесалия, гемангиома, капиллярная мальформация, STAMBP, галактоземия, GALT

Вклад авторов: О. А. Щагина - дизайн исследования, молекулярно-генетический анализ, оценка частот, статистическая обработка; Н. А. Семенова, Л. А. Бессонова - клиническое обследование и медико-генетическое консультирование семей больных; Е. А. Ларшина - биохимическое исследование, анализ гена GALT; Н. С. Бескоровайный - обработка массива экзомных данных; Е. Ю. Захарова - биохимическое исследование, расчет частоть болезни; О. П. Рыжкова - анализ патогенности вариантов, экзомное секвенирование; А. В. Поляков - выбор праймеров для молекулярногенетического анализа.

Соблюдение этических стандартов: исследование одобрено этическим комитетом Медико-генетического научного центра имени Н. П. Бочкова (протокол номер 5/8 от 12 ноября 2018 г.). Все пациенты или их законные представители подписали добровольное информированное согласие на проведение молекулярно-генетических исследований, публикацию клинических, молекулярно-генетических данных, включая фото- и видеоматериалы, с сохранением анонимности.

$\bigotimes$ Для корреспонденции: Ольга Анатольевна Щагина ул. Москворечье, д. 1, г. Москва, 115522; schagina@dnalab.ru, schagina_o@mail.ru

Статья получена: 18.05.2020 Статья принята к печати: 03.06.2020 Опубликована онлайн: 18.06 .2020

DOI: $10.24075 /$ vrgmu.2020.033

Microcephaly-capillary malformation syndrome (MICCAP: OMIM 614261) is a severe monogenic disorder inherited in an autosomal recessive manner. The patients have progressive microcephaly, deep mental retardation, early-onset drugresistant epilepsy and cutaneous capillary malformations due to abnormal capillary formation. Moreover, facial abnormalities, hypoplasia of distal phalanges and congenital heart defects are typical for a number of patients [1, 2].

The syndrome is associated with the STAMBP gene mutations The STAMBP protein is involved in the regulation 
of the ubiquitinated proteins' endosomal sorting, as well as in the trafficking them from endosomes to lysosomes. Endosomal sorting is a highly dynamic process essential for protein homeostasis regulation via receptor-mediated signal transduction active regulation and autophagy [3]. Impaired endosomal sorting leads to intracellular accumulation of ubiquitinated proteins $[4,5]$. Aggregated proteins cause the brain cells damage [6]. Meanwhile, the elevated level of GTP linked Ras protein (active form of Ras) has been revealed in the cell lines of patients affected with the STAMBP gene mutations, which indicates the involvement of the STAMBP protein in the Ras-MAPK signal transduction pathway [1]. It is known that capillary malformations are characteristic for various RASopathies since the mutations in the genes involved in the pathway are responsible for the congenital capillary formation abnormalities [7].

Currently there are less than 20 patients known to have MICCAP syndrome. Various types of the STAMBP gene mutations in the homozygous or compound heterozygous state have been identified in all patients [1, 8, 9]. Two patients with MICCAP syndrome have been reported in Russia: a girl with compound heterozygosity for the c.204-5C>G and c.273delA variants [10], and a boy with homozygosity for the $c .188 \mathrm{~A}>\mathrm{G}$ (p.Tyr63Cys) variant of the STAMBP gene [11].

The study was aimed to present the results of clinical examination and molecular genetic testing of three patients with MICCAP syndrome belonging to two unrelated families.

\section{Clinical cases}

Samples of DNA of the patients from two unrelated families (ST1 and ST5) and their relatives who referred to the Research Centre for Medical Genetics for consultation were analysed.

The analysis of the STAMBP gene (NM_201647.3) was carried out by automated Sanger sequencing with primers flanking each of the exons of the gene. For the proband of the ST5 family, the galactose-1-phosphate uridyl transferase activity was evaluated. The search for frequent mutations c.563A>G (p.Gln188Arg), c.855G>T (p.Lys285Asn) and c.940A $>$ G (p.N314D) polymorphic Duarte variant in the GALT gene (MIM 606999; RefSeq: NM_000155.3) was performed by RFLP analysis.

The results of sequencing 1036 exomes (2072 chromosomes) of the unrelated patiens living in Russia affected with various genetic disorders other than MICCAP were used as the control. The sequencing was performed with the IlluminaNextSeq 500 Sequencing System (Illumina; USA) using the IlluminaTruSeq ${ }^{\circledR}$ ExomeKit (Illumina; USA), and IDT $x$ Gen $^{\circledR}$ (IDT; USA) for sample preparation.

Statistical analysis was carried out using the MS Excel 2016 application (Microsoft Corporation; USA).

Family ST1. The proband was an affected boy ST1.1, born from the first pregnancy complicated by the lingering ARVI during the $1^{\text {st }}$ trimester and the threatened miscarriage since the beginning of the $2^{\text {nd }}$ trimester. Intrauterine growth retardation was diagnosed at 20 weeks of gestation. The delivery occurred at 38-39 weeks of gestation. The birth weight was $2540 \mathrm{~g}$, the birth length was $47 \mathrm{~cm}$, the head circumference was $32 \mathrm{~cm}$, and the Apgar score was 8/9. The boy developed normally until 3 -months old. At the age of 3 months the parents noted the first convulsive seizure (myoclonus) followed by rapid psychomotor regression.

$\mathrm{MRl}$ at the age of 4 months revealed the diffuse cortical and subcortical atrophy of the cerebral hemispheres. The sleep video-EEG monitoring revealed generalized, high-amplitude, polymorphic slow-wave hypersynchronous activity with spikeand-wave complexes. The predominance of spike-wave activity in the parieto-occipital regions of brain hemispheres throughout the time of investigation together with the recurrent pattern of hypsarrhythmia amplitude decrease were registered.

On admission, at the age of 1 year 7 months the boy was completely immobile, with vision and hearing loss, and he was fed via gavage. The seizures' duration and frequency dramatically increased. The anticonvulsant therapy had completely no effect. The boy's height was $81 \mathrm{~cm}$ ( $50^{\text {th }}$ percentile), the weight was $9.4 \mathrm{~kg}$ (below the $3^{\text {rd }}$ percentile), and the head circumference was $43 \mathrm{~cm}$ (below the $3^{\text {rd }}$ percentile). The patient had severe protein-energy undernutrition, microcephaly and mild positional skull deformity, multiple cutaneous hemangiomas over the buttocks, lumbar region, right thigh and back, moderate hypertrichosis over the forehead, bushy eyebrows and lashes (Fig. 1).

The child died at the age of 2.5 of the respiratory infection septic complication.

The proband's sibling was the affected boy ST1.4 born from the second pregnancy. Ultrasonography at 28-30 weeks of gestation revealed mismatch between the fetal head circumference and the gestational age. The boy was born in time, the birth weight was $3100 \mathrm{~g}$, the birth length was $51 \mathrm{~cm}$, and the head circumference was $32 \mathrm{~cm}$. At the age of 2 months the parents noted the first convulsive seizure. After that, multiple seizures occurred daily. The paroxysmal events consisted of sudden freezing and the upward rolling of the eyes. Until 2 months old the patient's development was age-appropriate. The bottle-fed infant experienced swallowing difficulties with frequent choking on. The parents complained about frequent squeaks, agitation with head bouncing associated with the increase in blood pressure up to $130 / 70 \mathrm{~mm} \mathrm{Hg}$, myoclonus of limbs even when falling asleep and sometimes during sleep, frequent sudden freezing together with gaze freezing, occasional salaam seizures, lack of eye contact. The patient received valproic acid and vigabatrin as an anticonvulsant therapy, against which the moderate positive changes were observed. The infant was examined by neurogenetics specialist at the age of 5 months. Phenotype: height $63 \mathrm{~cm}$ (50-75 ${ }^{\text {th }}$ percentile), weight $6820 \mathrm{~g}$ (50 $0^{\text {th }}$ percentile), head circumference $37 \mathrm{~cm}$ (below the $3^{\text {rd }}$ percentile), microcephaly, anterior fontanelle sized $2.5 \times 2.5 \mathrm{~cm}$, multiple cutaneous hemangiomas $0.5-2 \mathrm{~cm}$ in diameter. On admission, the infant failed to maintain gaze, fix eyes on objects and hold his head. The muscle tone was diffuse and moderately decreased, the reflexes were brisk. During the examination, paroxysmal events were repeatedly observed consisting of sudden freezing and upward rolling of the eyes. In addition, the infant's pronounced agitation, squeaks, myoclonus of limbs even during sleep and episodes of sudden freezing were noticeable. The continuous roving eye movements together with elements of horizontal and rotational nystagmus were noted. The tongue in the oral cavity was tense and raised up. The oral automatism reflexes were brisk. The tendon reflexes were brisk, with ankle clonus. The pronounced startle reflex was observed when touched. The patient demonstrated a developmental delay in his psychoemotional sphere.

Based on the clinical picture characterized by specific phenotypic manifestations (combination of microcephaly and capillary abnormalities), and the existence of two affected siblings, the patient was diagnosed with rare autosomal recessive disorder, the MICCAP syndrome. Since in all described patients the disease was caused by the STAMBP gene mutations, a search for mutations in that gene was carried out by automated Sanger sequencing. 
A

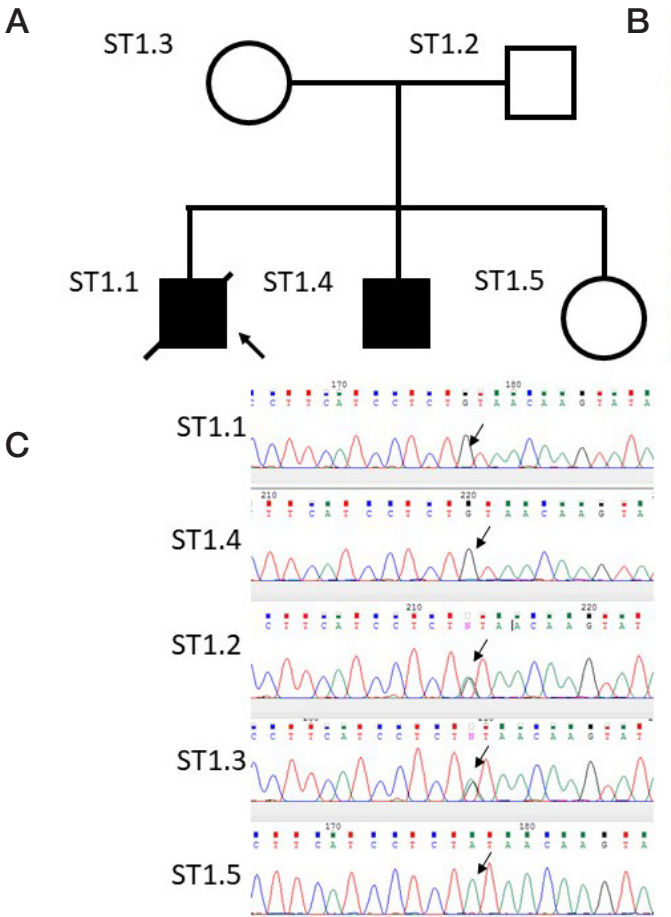

B

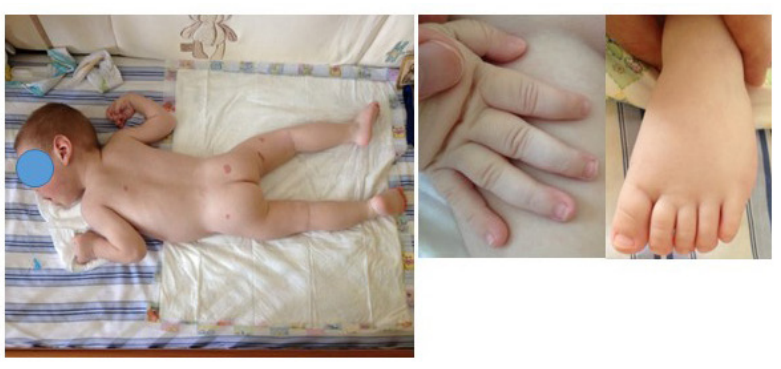

D

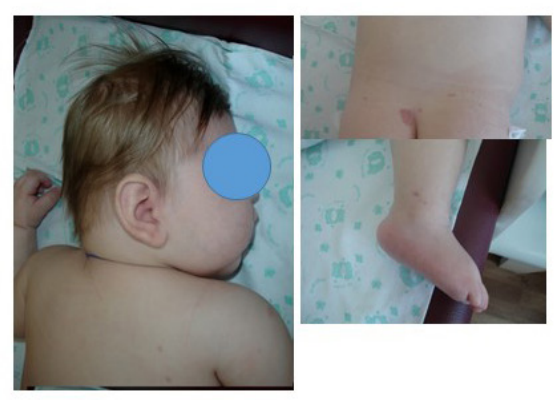

Fig. 1. Phenotype, pedigree and sequencing results for the ST1 family members. A. ST1 family pedigree. B. General appearance of patient ST1.1 at the age of 2. C. General appearance of patient ST1.4 at the age of 5. D. Sanger sequencing chromatograms for patient ST1.1, patient ST1.4, father (ST1.2), mother (ST1.3) and healthy sibling ST1.5 (proband is denoted by the arrow)

As a result, a STAMBP gene variant NM_201647.3: c.188A $>$ G (p.Tyr63Cys) in the homozygous state previously described twice in patients with MICCAP syndrome was identified $[1,11]$. Both parents turned out to be heterozygous carriers of the variant. According to the gnomAD database [12], the described gene allele frequency was 0.0000637. In the control group of exomes of Russian patients with various genetic disorders the described variant was detected in one chromosome of 2072, i. e. the frequency was 0.00048 (male patient born in 1973 diagnosed with hemophilia A having a pathogenic variant in the F8 gene). In Russia, the variant in the homozygous state was also reported in patient with MICCAP syndrome [11]. Among all patients with that syndrome known in Russia, the variant c.188A>G was identified in four independent chromosomes of eight. Thus, the prevalence of the variant in affected individuals was significantly higher than in the control group. The odds ratio (OR) calculated during the case-control study was 2071 (95\% Cl: 187-22849).

The STAMBP gene has a low level of benign missense variants, and the missense mutations are a common cause of MICCAP syndrome. Thus, in accordance with the ACMG criteria, the discribed variant has been recognized as likely pathogenic (PS4, PM2, PP2, PP3, PP5) [13].

Two years after the birth of a second child the third pregnancy occurred in the family. The parents applied for prenatal diagnosis of the fetus at 11-12 weeks of gestation. No changes in the STAMBP gene nucleotide sequence were identified. The pregnancy ended in the birth of healthy girl.

Family ST5. The ST5 family applied to refine the daughter's diagnosis. The 3-week old girl was the fourth child born wihin exogamous marriage of healthy parents. The family included other three children (healthy boy and girl, and a son with cerebral palsy, a pre-term baby born at 31 weeks of gestation). The maternal half-sibling (brother) was healthy. The mother had medical abortion and ectopic pregnancy in her history. The pregnancy was complicated by anemia, rhinopharyngitis and influenza vaccination at 35 weeks of gestation. The delivery occurred in time. The infant's birth weight was $2910 \mathrm{~g}\left(10^{\text {th }}\right.$ percentile), the birth length was $51 \mathrm{~cm}$ (50 $0^{\text {th }}$ percentile), the head circumference was $30 \mathrm{~cm}$ (below the $3^{\text {rd }}$ percentile), and the Apgar score was 8/8 (Fig. 2).

From birth, multiple flat roundish cutaneous hemangiomas not raised above the skin surface were visible on the trunk and limbs. After delivery, the infant was in moderately grave condition due to central nervous system depression syndrome. It was transferred to the intensive care unit for observation. There was no need in the respiratory support. On the $5^{\text {th }}$ day, the hyperbilirubinemia increase was registered, as well as cholestasis and cytosis (transaminase concentration increased five times to normal; the peak level of aspartate aminotransferase (AST) was $229 \mathrm{U} / \mathrm{l}$, the level of alanine aminotransferase (ALT) reached $143 \mathrm{U} / \mathrm{I})$. On the $10^{\text {th }}$ day of life the patient required a plasma transfusion due to coagulopathy. A complete blood count revealed normal hemoglobin level and normal platelets amount. Neurosonography on the $6^{\text {th }}$ day of life revealed echosigns of subependymal pseudocyst on the left side. The heart ultrasound revealed no heart defects, the atrial septal aneurysm together with functioning foramen ovale were noted. The neonatal screening center reported increased galactose level (the total galactose level remained unknown). The activity of galactose-1phosphate uridylyltransferase (GALT) was analyzed. A significant decrease in enzyme activity to $0.63 \mathrm{U} / \mathrm{gHb}$ was detected (normal value 4.4-15 U/gHb), which made up $7 \%$ of normal value.

Phenotype: microcephalic skull, microgenia, long philtrum; generalized multiple roundish "port-wine" stained cutaneous hemangiomas on the belly, back, buttocks and limbs. Hemangiomas faded slightly when pressed.

The study of frequent mutations NM_000155.3 in the GALT gene was carried out using PCR-RFLP analysis. The frequent pathogenic variants c.563A $>G$ (p.Gln188Arg) and c.855G>T (p.Lys285Asn) in heterozygous state were identified [14]. The examination of parents revealed the trans-position of the detected pathogenc variants (substitution c. 563A>G 
A

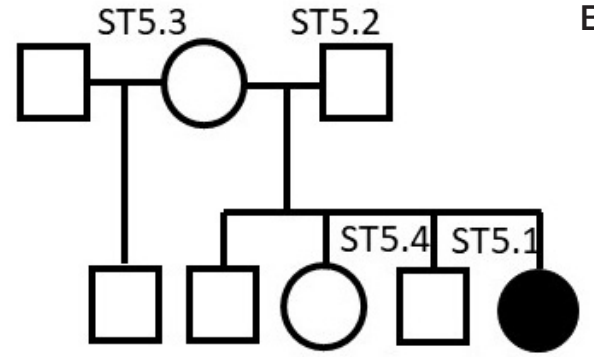

C

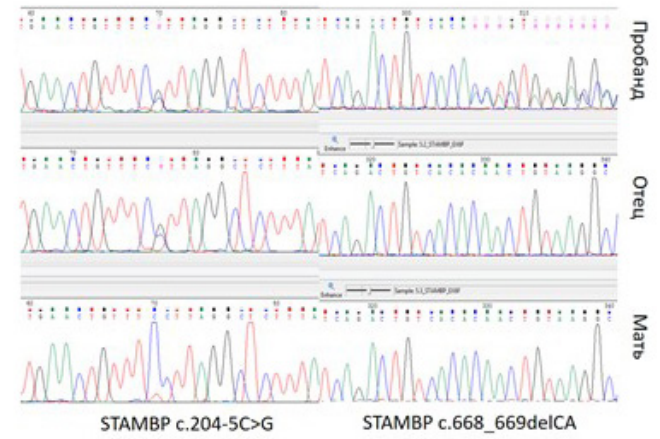

B

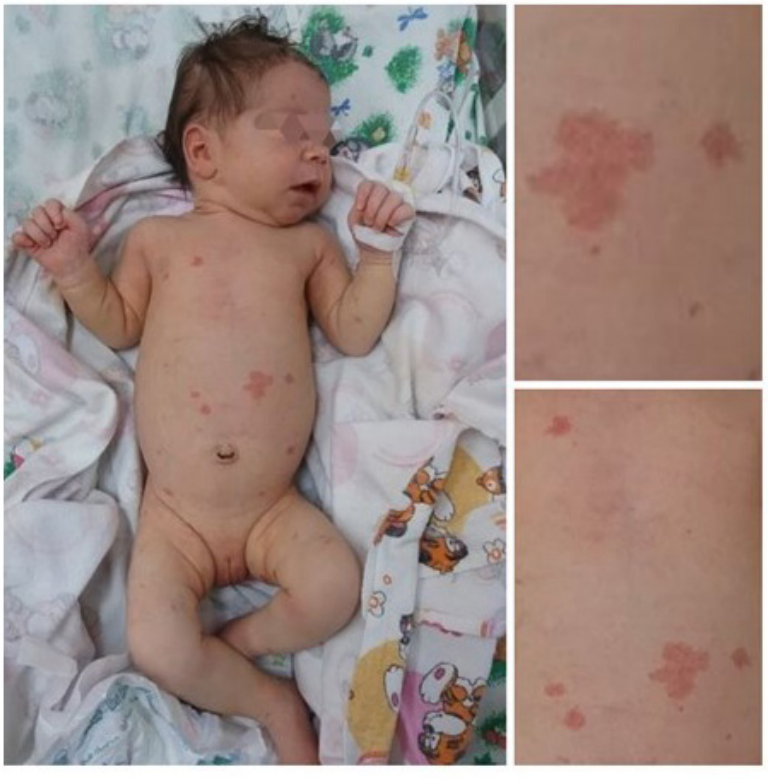

Fig. 2. Phenotype, pedigree and sequencing results for the ST5 family members. A. ST5 family pedigree. B. Patient's general appearance at the age of 3 weeks. C. Sanger sequencing chromatograms for proband, father and mother

(p.Gln188Arg) was inherited from mother, and c.855G>T (p.Lys285Asn) was inherited from father).

The study of STAMBP gene identified variants c.2045C>G and c.668_669delCA in heterozygous state. The variant NM_201647.3:C.204-5C>G (rs746354315) was previously reported as likely pathogenic in Russian female patient with MICCAP syndrome, in compound heterozygous state with pathogenic variant c.273delA [10]. According to gene prediction programs, the described variant affected splicing. According to gnomAD database, the frequency of the variant was 0.00000399. In the control group of exomes of Russian patients with various genetic disorders the variant was identified in one chromosome of 2072, and the frequency of the variant was 0.00048 (in female patient born in 1980, being a mother of proband diagnosed with expressive language delay). Among all patients with MICCAP syndrome known in Russia, the variant c.204-5C> $\mathrm{G}$ was identified in two independent chromosomes of eight. Thus, the prevalence of the variant in affected individuals was significantly higher than in the control group. The odds ratio $(\mathrm{OR})$ calculated during the case-control study was 690 (95\% Cl: 55-8672). According to the ACMG criteria, the variant c.204-5C>G was pathogenic (PS4, PM2, PM3, PP4, PP5) [13]. The variant NM_201647.3:c.668_669delCA was responsible for frameshift and formation of premature termination codon p.Thr223AsnfsTer6. The described deletion had not been reported previously in patients with MICCAP syndrome. The variant was not registered in the gnomAD database and in the control group of the Russian patients' exomes. The study of relatives revealed the variant c.204-5C>G in heterozygous state in patient's parents and sibling. The variant c.668_669delCA was not detected in proband's parents and sibling. Maternity and paternity were established using the microsatellite markers. According to the ACMG criteria, the variant was pathogenic (PVS1, PS2, PM2, PP4) [13].

The family decided not to pursue further the study in order to define the cis-trans position of variants at the RNA level due to the nontransportable infant's severe grave condition and lack of plans for further reproduction.
Heterozygous variants at exons and splicing sites of the STAMBP gene, the allele frequency of which was lower than $1 \%$ in the gnomAD database, were selected in 1036 exomes of Russian patients. The variants' pathogenicity was assessed in accordance with the ACMG criteria using the VarSome application [15] (Table 1).

The carrier frequency was estimated and the prevalence of MICCAP syndrome in the Russian Federation was calculated based on the frequencies of pathogenic (PAT) and likely pathogenic (LPAT) variants of the STAMBP gene (see Table 1, denoted with bold). In the exomes of residents of the Russian Federation the pathogenic and likely pathogenic STAMBP gene variants in heterozygous state were detected in 6 people of 1,036. According to data received, STAMBP gene mutations carrier frequency was one per 173 people (1/126-1/299). Thus, the prevalence of the disorder in the Russian Federation is likely to be one per 120,000 (Cl: 1/356 724-1/62 691).

The phenotype of proband ST5.1 was caused by combination of two autosomal recessive genetic disorders: galactosemia and MICCAP syndrome. Severe grave condition during the neonatal period (cytosis, cholestasis, coagulopathy) was due to metabolic disorders associated with the GALT gene mutations. The STAMBP gene mutations were responsible for microcephaly, capillary malformations, and low birth weight. The galactosemia manifestations were adjusted in the first year of life. However, overlaying seizures and severe central nervous system damage due to MICCAP syndrome made the patient's prognosis unfavorable.

The main clinical data of patients are presented in Table 2. The clinical manifestations of the syndrome in all examined patients were quite typical: all patients had congenital microcephaly and multiple cutaneous capillary malformations which not shrinked but increased with the infants' growth. During infancy, epilepsy with polymorphic seizures debuted resistant to anticonvulsant therapy. All examined infants had profound psychomotor development delay and neurological deficit. One of the patients had hypoplastic phalanges of fingers and nails, and the siblings of the ST1 family had myoclonus of limbs and roving eye movements. Severe central nervous system damage is typical 
Table 1. STAMBP gene variants found in the exomes of residents of the Russian Federation

\begin{tabular}{|c|c|c|c|c|}
\hline \multicolumn{2}{|c|}{ Variant } & \multirow{2}{*}{$\begin{array}{l}\text { Number of chromosomes } \\
\text { with variants }\end{array}$} & \multirow{2}{*}{$\begin{array}{l}\text { Allele frequency (2072 } \\
\text { chromosomes) }\end{array}$} & \multirow{2}{*}{$\begin{array}{c}\text { Pathogenicity } \\
\text { ACMG [13] }\end{array}$} \\
\hline Position (GRCh37/hg19) & Effect & & & \\
\hline chr2-74058017-G-A & c.34G>A p.Glu12Lys & 1 & 0.00048 & $\begin{array}{c}\text { VUS } \\
\text { (PM1,PM2,PP2) }\end{array}$ \\
\hline chr2-74058041-C-A & c.58C $>$ A p.Gln20Lys & 1 & 0.00048 & $\begin{array}{c}\text { VUS } \\
\text { (PM1,PM2,PP2,BP4) }\end{array}$ \\
\hline chr2-74058095-C-A & c. $112 C>A$ p.Arg38Ser & 1 & 0.00048 & $\begin{array}{c}\text { LP } \\
\text { (PM1,PM2,PM5,PP2,PP3) } \\
\end{array}$ \\
\hline chr2-74058143-G-T & c.160G>T p.Gly54Cys & 1 & 0.00048 & $\begin{array}{c}\text { LP } \\
\text { (PM1,PM2,PP2,PP3) }\end{array}$ \\
\hline chr2-74058171-A-G & c. $188 \mathrm{~A}>\mathrm{G}$, p.Tyr63Cys & 1 & 0.00048 & $\begin{array}{c}\text { LP } \\
\text { (PS4,PM2,PP2, PP3,PP5) }\end{array}$ \\
\hline chr2-74071935-C-G & c. $204-5 C>G$ & 1 & 0.00048 & $\begin{array}{c}\text { PAT } \\
\text { (PS4,PM2,PM3,PP4,PP5) }\end{array}$ \\
\hline chr2-74072291-C-A & c. $280-3 C>A$ & 1 & 0.00048 & $\begin{array}{c}\text { VUS } \\
\text { (PM2,BP4) }\end{array}$ \\
\hline hr2-74072359-C-A & c.345C>A p.Thr115Thr & 1 & 0.00048 & $\begin{array}{c}\text { VUS } \\
\text { (PM2,BP7) }\end{array}$ \\
\hline chr2-74074592-C-T & c. $454 \mathrm{C}>\mathrm{T}$ p.G $\ln 152^{*}$ & 2 & 0.00096 & $\begin{array}{c}\text { PAT } \\
\text { (PVS1 PM2,PP3) } \\
\end{array}$ \\
\hline chr2-74074722-C-T & c.584C>T p.Pro195Leu & 1 & 0.00048 & $\begin{array}{c}\text { VUS } \\
\text { (PM2,PP2,BP4) }\end{array}$ \\
\hline chr2-74074796-G-A & c.658G>A p.Asp220Asn & 2 & 0.00096 & $\begin{array}{c}\text { VUS } \\
\text { (PM2,PP2,BP4) }\end{array}$ \\
\hline chr2-74074815-G-A & c.677G>A p.Arg226Lys & 1 & 0.00048 & $\begin{array}{c}\text { VUS } \\
\text { (PM2,PP2,BP4) }\end{array}$ \\
\hline chr2-74076511-G-A & c.764G>A p.Arg255His & 5 & 0.0024 & $\begin{array}{c}\text { VUS } \\
\text { (PP2,PP3,BP4) } \\
\end{array}$ \\
\hline chr2-74076532-G-T & c.785G>T p.Arg262Leu & 1 & 0.00048 & $\begin{array}{c}\text { VUS } \\
\text { (PM2,PP2,PP3) }\end{array}$ \\
\hline chr2-74076576-C-A & c.829C >A p.Arg277Arg & 1 & 0.00048 & $\begin{array}{c}\text { VUS } \\
\text { (PM2,BP7) }\end{array}$ \\
\hline chr2-74077551-G-A & c.916G>A p.Ala306Thr & 1 & 0.00048 & $\begin{array}{c}\text { VUS } \\
\text { (PM2,PP2,BP4) }\end{array}$ \\
\hline chr2-74086389-C-A & c.1014C>A p.Pro338Pro & 1 & 0.00048 & $\begin{array}{c}\text { VUS } \\
\text { (PM2,BP7) }\end{array}$ \\
\hline
\end{tabular}

for MICCAP syndrome, the patients often die early due to septic complications (like the elder affected boy of the family ST1).

\section{Discussion}

The currently existing literature data make it possible to define the "core" of the syndrome: microcephaly, intractable neonatal seizures, profound psychomotor development delay and the unique manifestation, the randomly arranged multiple red spots which do not shrink with age. The examined patients had all the listed signs. According to literature data, the infants with MICCAP syndrome may have dysmorphic facial features: low anterior hairline, sloping forehead, epicanthus, ptosis, low-set ears, micrognathia, short nose. The examined patients also had some facial abnormalities: these were low anterior hairline in proband ST1.1, microgenia and long philtrum in patient ST5.1. Many authors report brachydactyly and nail hypoplasia. However, the digital features (shortening) of hands and feet were present only in the girl of the family ST5.1. On the contrary, myoclonus of limbs together with rowing eye movements were observed in patients of the famly ST1 and abscent in the family ST5.1 [7-11]. Thus, the presence and severity of phenotype features in various patients (except for microcephaly and spots on the skin) may be variable and probably depend on the genotype.

The combination of two genetic disorders in patient ST5.1 is a rare case. Such combination is particularly difficult in newborns, when there is a need for quick decision making in order to save the life and stabilize the patient. According to estimates, the prevalence of galactosemia in Russia in from $1: 60,000$ to $1: 70,000$ newborns, and the predicted MICCAP syndrome prevalence is even lower, 1 per 120,000 [16, 17]. The probability of two rare genetic disorders in one patient is extremely low. However, the reported case demonstrates that such combination may occur, and therefore should be considered when defining tactics of treatment, family planning and genetic counseling of families.

\section{CONCLUSION}

MICCAP syndrome is a rare genetic disorder. Currently less than 20 patients in the world have been reported to have MICCAP. Congenital microcephalies are the large heterogenous group of genetic disorders. However, the specific clinical symptom, the presence of multiple capillary malformations, makes it possible to suspect a particular disorder associated with mutations of the STAMBP gene. The study of the gene allows one to quickly find the molecular genetic cause of the disorder.

The reported case of galactosemia and MICCAP syndrome combination in one patient demonstrates that despite the low probability of two rare genetic disorders in one individual the described variant should be considered when defining the tactics of diagnosis and therapy for each particular family. 
Table 2. Comparison of patients with MICCAP syndrome

\begin{tabular}{|c|c|c|c|}
\hline Trait & ST1.1 & ST1.4 & ST5.1 \\
\hline STAMBP genotype & c. $[188 \mathrm{~A}>\mathrm{G}] ;[188 \mathrm{~A}>\mathrm{G}]$ (p.Tyr63Cys) & c. $[188 \mathrm{~A}>\mathrm{G}] ;[188 \mathrm{~A}>\mathrm{G}]$ (p.Tyr63Cys) & c. [204-5c>g(;) 668_669delCA] \\
\hline Gender & M & M & $f$ \\
\hline Age of onset & 3 months & 2 months & 6 months \\
\hline Congenital microcephaly & + & + & + \\
\hline Birth head circumference & $<4^{\text {th }}$ percentile & $<4^{\text {th }}$ percentile & $<3^{\text {rd }}$ percentile \\
\hline Head circumference upon admission & $<3^{\text {rd }}$ percentile & $<3^{\text {rd }}$ percentile & $<3^{\text {rd }}$ percentile \\
\hline Capillary malformations & + & + & + \\
\hline Small for gestational age & + & - & + \\
\hline Early-onset resistant seizures & + & + & + \\
\hline Myoclonus & + & + & - \\
\hline Hypoplastic phalanges & - & - & + \\
\hline Profound developmental delay & + & + & + \\
\hline Additional information & Died at the age of 2.5 & & $\begin{array}{c}\text { Galactosemia } G A L T \\
\text { c. }[563 A>G] ;[c .855 G>T]\end{array}$ \\
\hline
\end{tabular}

In one of the reported patients, the new nucleotide sequence variant was identified, which had not been described before in the literature and databases. That makes it possible to expand knowledge of the MICCAP syndrome allele heterogeneity. The provided information on genotypes and phenotypes of the affected individuals may be of interest to scientists studying clinical genetic correlations and STAMBP protein functions.

\section{References}

1. McDonell LM, Mirzaa GM, Alcantara D, Schwartzentruber J Carter MT, Lee LJ, et al. Mutations in STAMBP, encoding a deubiquitinating enzyme, cause microcephaly-capillary malformation syndrome. Nat Genet. 2013; 45: 556-62. Available from: https://doi.org/10.1038/ng.2602.

2. Mirzaa GM, Paciorkowski AR, Smyser CD, Willing MC, Lind AC, Dobyns WB. The microcephaly-capillary malformation syndrome. Am J Med Genet Part A. 2011; Part A 155: 2080-7. DOI: 10.1002/ ajmg.a.34118.

3. Tanaka N, Kaneko K, Asao H, Kasai H, Endo Y, Fujita T, et al. Possible involvement of a novel STAM-associated molecule "AMSH" in intracellular signal transduction mediated by cytokines. J Biol Chem. 1999; 274: 19129-35. DOI: 10.1074/ jbc.274.27.19129.

4. McCullough J, Row PE, Lorenzo Ó, Doherty M, Beynon R, Clague MJ, et al. Activation of the endosome-associated ubiquitin isopeptidase AMSH by STAM, a component of the multivesicula body-sorting machinery. Curr Biol. 2006; 16 (2): 160-5. DOI: 10.1016/j.cub.2005.11.073.

5. Tsang HTH, Connell JW, Brown SE, Thompson A, Reid E, Sanderson CM. A systematic analysis of human CHMP protein interactions: Additional MIT domain-containing proteins bind to multiple components of the human ESCRT III complex. Genomics. 2006; 88 (3): 333-46. DOI: 10.1016/j.ygeno.2006.04.003.

6. Suzuki S, Tamai K, Watanabe M, Kyuuma M, Ono M, Sugamura K, et al. AMSH is required to degrade ubiquitinated proteins in the central nervous system. Biochem Biophys Res Commun. 2011; 408 (4): 582-8. DOI: 10.1016/j.bbrc.2011.04.065.

7. Boon LM, Mulliken JB, Vikkula M. RASA1: Variable phenotype with capillary and arteriovenous malformations. Current Opinion in Genetics and Development. 2005; 15 (3): 265-9. DOI: 10.1016/j. gde.2005.03.004.

8. Naseer MI, Sogaty S, Rasool M, Chaudhary AG, Abutalib YA, Walker $S$, et al. Microcephaly-capillary malformation syndrome: Brothers with a homozygous STAMBP mutation, uncovered by exome sequencing. Am J Med Genet Part A. 2016; 170 (11): 3018-22. DOI: 10.1002/ajmg.a.37845.

9. Wu F, Dai Y, Wang J, Cheng M, Wang Y, Li X, et al. Early-onset epilepsy and microcephaly-capillary malformation syndrome caused by a novel STAMBP mutation in a Chinese boy. Mol Med Rep. 2019; 20 (6): 5145-51. DOI: 10.3892/mmr.2019.10757.

10. Demikova NS, Kakaulina VS, Pechatnikova NL, Polyakova NA, Zaharova EY, Krylova TD, et al. Hydrocephalus syndrome with capillary malformations. Pediatria (Santiago). 2016; 95 (5): 110-14.

11. Schugareva LM, Poteshkina OV. The Microceph aly-Capillary Malformation Syndrome. Russ Neurosurg J named after Profr AL Polenov. 2018; X (1): 74-9.

12. Genome Aggregation Database (gnomAD). Available from: https:// gnomad.broadinstitute.org/.

13. Richards S, Aziz N, Bale S, Bick D, Das S, Gastier-Foster J, et al. Standards and guidelines for the interpretation of sequence variants: A joint consensus recommendation of the American College of Medical Genetics and Genomics and the Association for Molecular Pathology. Genet Med. 2015; 17: 405-23. DOI: 10.1038/gim.2015.30.

14. Coelho Al, Trabuco M, Ramos R, Silva MJ, Almeida IT de, Leandro P, et al. Functional and structural impact of the most prevalent missense mutations in classic galactosemia. Mol Genet Genomic Med. 2014; 2(6): 484-96. DOI: 10.1002/mgg3.94.

15. Kopanos C, Tsiolkas V, Kouris A, Chapple CE, Albarca Aguilera M, Meyer R, et al. VarSome: the human genomic variant search engine. Bioinformatics. 2019; 35 (11): 1978-80. DOI: 10.1093/ bioinformatics/bty897.

16. Voskoboeva EY, Baydakova GV, Denisenkov Al, Denisenkova EV, Zakharova EY. Galactosemia in Russia: molecular characteristics, neonatal screening, verifying diagnostics. Med Genet. 2009; 8 (6): 25-33.

17. Novikov PV, Khodunova AA. The first results of extended newborn screening for hereditary metabolic diseases in the Russian Federation. Ros Vestn Perinatol Pediat. 2012; (5): 5-12. 


\section{Литература}

1. McDonell LM, Mirzaa GM, Alcantara D, Schwartzentruber J Carter MT, Lee LJ, et al. Mutations in STAMBP, encoding a deubiquitinating enzyme, cause microcephaly-capillary malformation syndrome. Nat Genet. 2013; 45: 556-62. Available from: https://doi.org/10.1038/ng.2602.

2. Mirzaa GM, Paciorkowski AR, Smyser CD, Willing MC, Lind AC, Dobyns WB. The microcephaly-capillary malformation syndrome. Am J Med Genet Part A. 2011; Part A 155: 2080-7. DOI: 10.1002/ ajmg.a.34118.

3. Tanaka N, Kaneko K, Asao H, Kasai H, Endo Y, Fujita T, et al. Possible involvement of a novel STAM-associated molecule "AMSH" in intracellular signal transduction mediated by cytokines. J Biol Chem. 1999; 274: 19129-35. DOI: 10.1074/ jbc.274.27.19129.

4. McCullough J, Row PE, Lorenzo Ó, Doherty M, Beynon R, Clague MJ, et al. Activation of the endosome-associated ubiquitin isopeptidase AMSH by STAM, a component of the multivesicular body-sorting machinery. Curr Biol. 2006; 16 (2): 160-5. DOI: 10.1016/j.cub.2005.11.073

5. Tsang HTH, Connell JW, Brown SE, Thompson A, Reid E, Sanderson CM. A systematic analysis of human CHMP protein interactions: Additional MIT domain-containing proteins bind to multiple components of the human ESCRT III complex. Genomics. 2006; 88 (3): 333-46. DOI: 10.1016/j.ygeno.2006.04.003.

6. Suzuki S, Tamai K, Watanabe M, Kyuuma M, Ono M, Sugamura K, et al. AMSH is required to degrade ubiquitinated proteins in the central nervous system. Biochem Biophys Res Commun. 2011; 408 (4): 582-8. DOI: 10.1016/j.bbrc.2011.04.065.

7. Boon LM, Mulliken JB, Vikkula M. RASA1: Variable phenotype with capillary and arteriovenous malformations. Current Opinion in Genetics and Development. 2005; 15 (3): 265-9. DOI: 10.1016/j. gde.2005.03.004.

8. Naseer MI, Sogaty S, Rasool M, Chaudhary AG, Abutalib YA, Walker $\mathrm{S}$, et al. Microcephaly-capillary malformation syndrome: Brothers with a homozygous STAMBP mutation, uncovered by exome sequencing. Am J Med Genet Part A. 2016; 170 (11): 3018-22. DOI: 10.1002/ajmg.a.37845.
9. Wu F, Dai Y, Wang J, Cheng M, Wang Y, Li X, et al. Early-onset epilepsy and microcephaly-capillary malformation syndrome caused by a novel STAMBP mutation in a Chinese boy. Mol Med Rep. 2019; 20 (6): 5145-51. DOI: 10.3892/mmr.2019.10757.

10. Демикова Н. С., Какаулина В. С., Печатникова Н. Л., Полякова Н. А., Захарова Е. Ю., Крылова Т. Д. и др. Синдром микроцефалии с капиллярными мальформациями. Педиатрия. 2016; 95 (5): 110-14.

11. Щугарева Л. М., Потешкина О. В. Микроцефальнокапиллярный мальформационный синдром. Российский нейрохирургический журнал имени А. Л. Поленова. 2018; X (1): 74-9.

12. Genome Aggregation Database (gnomAD). Available from: https:// gnomad.broadinstitute.org/.

13. Richards S, Aziz N, Bale S, Bick D, Das S, Gastier-Foster J, et al. Standards and guidelines for the interpretation of sequence variants: A joint consensus recommendation of the American College of Medical Genetics and Genomics and the Association for Molecular Pathology. Genet Med. 2015; 17: 405-23. DOI: 10.1038/gim.2015.30.

14. Coelho Al, Trabuco M, Ramos R, Silva MJ, Almeida IT de, Leandro P, et al. Functional and structural impact of the most prevalent missense mutations in classic galactosemia. Mol Genet Genomic Med. 2014; 2(6): 484-96. DOI: 10.1002/mgg3.94.

15. Kopanos C, Tsiolkas V, Kouris A, Chapple CE, Albarca Aguilera M, Meyer R, et al. VarSome: the human genomic variant search engine. Bioinformatics. 2019; 35 (11): 1978-80. DOI: 10.1093/ bioinformatics/bty897.

16. Воскобоева Е. Ю., Байдакова Г. В., Денисенков А. И., Денисенкова Е. В., Захарова Е. Ю. Галактоземия в России: молекулярно-генетические особенности, неонатальный скрининг, подтверждающая диагностика. Медицинская генетика. 2009; 8 (6): 25-33.

17. Новиков П.В., Ходунова А. А. Первые итоги расширенного неонатального скрининга на наследственные болезни обмена веществ в Российской Федерации. Российский вестник перинатологии и педиатрии. 2012; (5): 5-12. 